\title{
Occurrence of Dendrocephalus brasiliensis Pesta, 1921 (Crustacea, Anostraca) in the Caras river, southern Ceara, Brazil
}

\author{
FRANCISCO R.V. FREITA, ISIS C. DE LUCENA, DAMARES R. ALENCAR, \\ ISRAEL J.M. SANTOS and ALLYSSON P. PINHEIRO \\ Laboratory of Carcinology (LACRUSE), Regional University of Cariri, Department of Science \\ Chemistry and Biology, Rua Cel. Antônio Luiz Pimenta, 1161, 63105-000 Crato, CE, Brazil
}

Manuscript received on July 28, 2016; accepted for publication on December 5, 2016

\begin{abstract}
:
Occurrence of Dendrocephalus brasiliensis Pesta, 1921 (Crustacea, Anostraca) in the Caras river, southern Ceara, Brazil. The specimens were collected in March and April 2014. The new occurrence extends the distribution and update area of occupancy of the species, which is characterized by a specific habitat: temporary lakes.
\end{abstract}

Key words: branchiopoda, fairy shrimp, aquiculture, fresh water.

\section{INTRODUCTION}

The fairy shrimp, Dendrocephalus brasiliensis Pesta, 1921 (Crustacea, Anostraca), is a freshwater, filterer Branchiopoda that is common in different states of Brazil. The geographical distribution of the species extends from Argentina to the state of Piauí, northeastern Brazil (Cohen 1995). The first record of the occurrence of Dendrocephalus in Brazil was made by Pesta (1921) in the states of Bahia and Piauí. Adolpho Lutz, otherwise, registered the occurrence in Macaiba, Rio Grande do Norte-RN, in 1929, from the species Dendrocephalus ornatus, by its bright scarlet color. Linder (1941), in turn, verified that the species described by Lutz (1929) was actually Dendrocephalus brasiliensis that Pesta wrote about in 1921.

Correspondence to: Francisco Ronaldo Vieira Freita

E-mail: ronaldofreita@hotmail.com
Among crustaceans, fairy shrimp stand out due to their occurrence in adverse environments, tolerating the most diverse and extreme environmental conditions. One of the most wellknown representatives of this group is the genus Artemia Leach, 1819, which is restricted to coastal saltwater habits and saltwater inland lakes (Vanhaecke et al. 1987). Freshwater fairy shrimps are found in semi-arid regions characterized by striking periods of drought, followed by rainy seasons that form temporary lakes and pools, which constitute the habitat of these crustaceans (Belk and Cole 1975).

According to Lopes et al. (1998) and Lopes (2007), Dendrocephalus brasiliensis is as an alternative food source for larvae and fingerlings of different species of carnivorous fish, as it has similar or higher protein levels than other organisms used in large-scale aquiculture activities around the 
world. Moreover, this species achieves a greater production of biomass in comparison to Artemia spp. (Lopes et al. 1998).

Here we report a new occurrence of $D$. brasiliensis from a lake in the southern portion of the state of Ceará (northeastern Brazil), which extends its distribution to the Carás River basin. This paper broadens the biogeographical information on the area of occupancy D. brasiliensis, extending its distribution since there are no continuous records of its occurrence in Brazilian states.

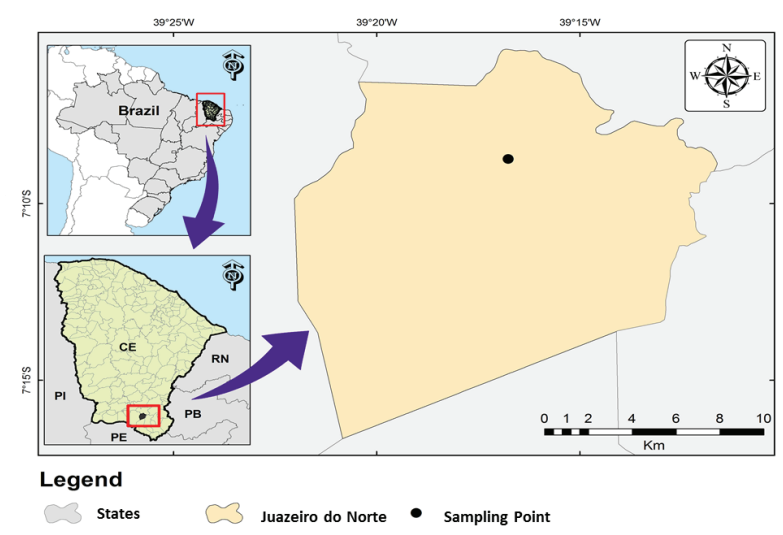

Figure 1 - 'Map of the municipality of Juazeiro do Norte, northeastern Brazil, Black spot: sampling site ( $7^{\circ} 08^{\prime} 44.64$ " S, 39०16' 45.37' W).

Some of the females had cysts, the characteristics of which are eight spherical, pentagonal concavities of the same size, with grooves with a smooth surface and dark coloration, as described by Lopes (2007).

The specimens were caught in a small, temporary, artificial lake near the Carás River in March and April 2014 and were deposited in the Semi-Arid Crustacean Laboratory (LACRUSE) of the Cariri Regional University under accession number LACRUSE \#0198.

The identification and sexing of the specimens was performed based on external morphological characteristics: males (Figure 2a) - structure of the antennae and developed, branched frontal appendage; females (Figure 2b) - lobules on first paws, ovigerous sac and cyst morphology (Cohen 1995, Rabet and Thiéry 1996).

Dendrocephalus brasiliensis has the following morphological characteristics: absence of spines on the anterior margin of the basal portion of the frontal appendages; foot-shaped termination of the ramification; absence of a spine on the lower margin of the eye; and absence of a lobe with a spine on the first pair of endopodites (Pereira 1983, Belk and Pereira 1982, Rabet and Thiéry 1996).

\section{RESULTS AND DISCUSSION}

This paper updates the information's about the occurrence of the D. brasiliensis, expanding its distribution area to the Carás River's basin in the southern of the Ceará, which is a semi-arid region in northeastern Brazil. The occurrence of the species in March and April, which corresponded to the months of higher volumes of rainfall in this region of the country, likely determines the reproductive period of the species, which has a lifecycle of approximately 70 to 80 days on average (Lopes 2007). The specimens were found in artificial lakes, characterized mainly by drying up during the drought period and filling during the rainy period, which is in agreement with the description of the main habitat of the species offered by Belk and Cole (1975).

\section{CONCLUSIONS}

This paper offers new information on the occurrence of $D$. brasiliensis that could give assistance to future studies addressing the species, as this is the most studied fairy shrimp and used in aquiculture as live food (cysts and nauplii) or frozen food (biomass) for fish and shrimp (Câmara 2000, Yflaar and Olivera 2003). 


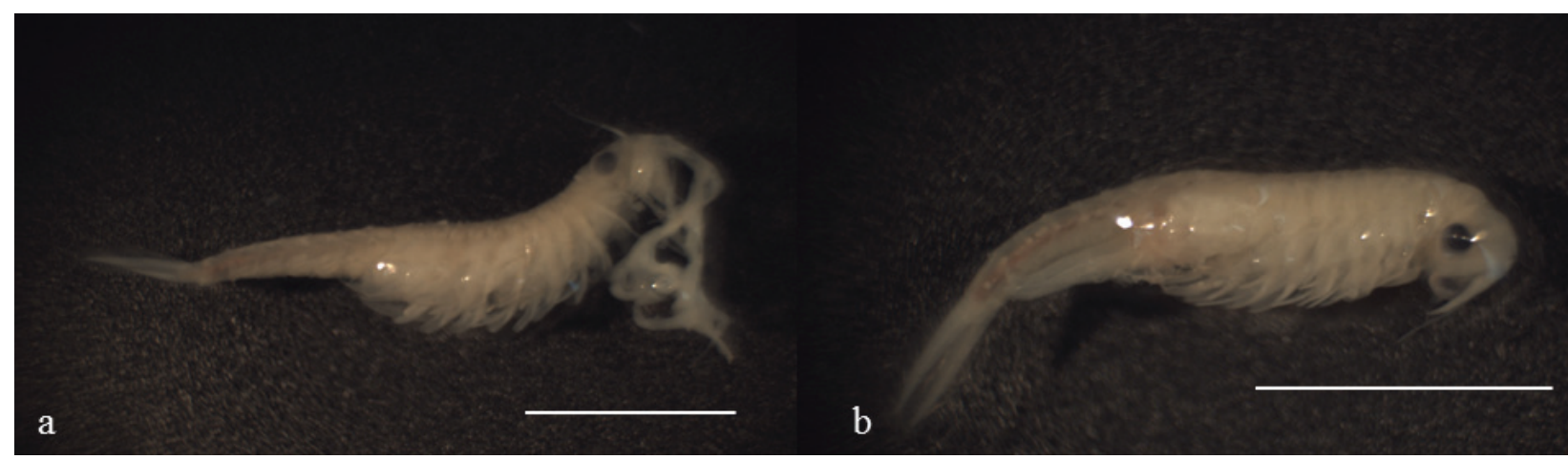

Figure 2 - Specimens of Dendrocephalus brasiliensis collected from Carás River basin, Juazeiro do Norte, Ceará, Brazil. (a) male; (b) female. ; Scale: $0.5 \mathrm{~mm}$.

\section{ACKNOWLEDGMENTS}

We thank the Cariri Regional University, where the analyses of the species were performed, to Mr. José Hélio Ribeiro Lima Junior, owner of the sampling site.

\section{REFERENCES}

BELK D AND COLE GA. 1975. Adaptational biology of desert temporary-pond inhabitants. In: Hadley NF (Ed), Environmental Physiology of Desert Organisms. Dowden, Hutchinson \& Ross, Inc., Pennsylvania, USA, p. 207-226.

BELK D AND PEREIRA G. 1982. Thamnocephalus venezuelensis, new species (Anostraca: Thamnocephalidae), first report of Thamnocephalus in South America. J Crustacean Biol 2: 223-226.

CÂMARA MR. 2000. Artemia no Brasil: do extrativismo ao cultivo. Rev Panor Aquicult 10(62): 15-19.

COHEN RG. 1995. Crustacea Anostraca in: Lopretto EC and Tell G (Eds), Ecossistemas de Águas Continentais: Metodologia para su Estudio. La Plata, Editiones SUR Tomo II, p. 871-895.

LINDER F. 1941. Contributions to the morphology and the taxonomy of the Branchiopoda Anostraca. Zoologiska Bidrag från Uppsala 20: 101-303.
LOPES JP. 2007. Produção de cistos de branchoneta, Dendrocephalus brasiliensis (Crustacea: Anostraca). Rev Biotemas 20(2): 33-39.

LOPES JP, SILVA NLA, SANTOS GJA AND TENÓRIO RA. 1998. Branchoneta - Uma notável contribuição à larvicultura e alevinagem de peixes carnívoros de água doce. Panor Aquicult 8: 31-34.

LUTZ A. 1929. Dous phyllopodes, observados no Rio Grande do Norte. Mem Del Inst Oswaldo Cruz, Rio de Janeiro 5, p. 3-9.

PEREIRA G. 1983. Taxonomic importance of the frontal appendage in the genus Dendrocephalus (Anostraca: Thamnocephalidae). J Crustacean Biol 3: 293-305.

PESTA O. 1921. Kritische Revision der Branchipodidensammlung der Wiener Naturhistorischen Staats-Museum. Ann Naturh MusWien 34: 80-98.

RABET N AND THIERY A. 1996. The neotropical genus Dendrocephalus (Anostraca: Thamnocephalidae) in Brazil (South America), with a description of two new species. J Nat Hist 30: 479-503.

VANHAECKE P, TACKAERT W AND SORGELOOS P. 1987. The biogeography of Artemia: an updated review. In: Artemia research and its applications. Morphology, genetics, strain characterization, toxicology. Universa Press, Wetteren, Belgium 1, p. 129-155.

YFLAAR BZ AND OLIVERA A. 2003. Utilização de náuplios de "branchoneta" Dendrocephalus brasiliensis (Pesta, 1921) na alimentação de larvas do "camarão cinza" Litopenaeus vannamei (Boone, 1931). Ac Scientiarum 25: p. 299-307. 